\title{
STAN TECHNICZNY PRZEDWOJENNYCH BUDYNKÓW W OBLICZU NOWYCH INWESTYCJI KOMUNIKACYJNYCH NA PRZYKŁADZIE KAMIENICY Z 1912 ROKU
}

\author{
Marek Dohojda, Katarzyna Jeleniewicz ${ }^{凶}$, Joanna Witkowska-Dobrev, \\ Olga Szlachetka
}

Instytut Inżynierii Lądowej, Szkoła Główna Gospodarstwa Wiejskiego w Warszawie

\begin{abstract}
STRESZCZENIE
Przedmiotem pracy jest analiza problemu oddziaływania nowych inwestycji budowlanych na już istniejące obiekty w zwartej zabudowie miejskiej. Problem w pracy omówiono dwutorowo. Po pierwsze określono grupy czynników nowej inwestycji budowlanej wpływające na sąsiednie obiekty. Po drugie oceniono stan techniczny istniejących obiektów, wskazano sposoby jego poprawy lub technologie, które mają także minimalizować negatywne oddziaływanie sąsiednich inwestycji. Zagadnienie omówiono w pracy na przykładzie przedwojennego budynku zlokalizowanego w dzielnicy Praga Północ w Warszawie.
\end{abstract}

Słowa kluczowe: ocena stanu technicznego, budynki przedwojenne, inwestycje komunikacyjne, strefa oddziaływania inwestycji

\section{WSTĘP}

Współczesne budownictwo miejskie napotyka wiele problemów. Jednym z nich jest realizacja inwestycji w zwartej zabudowie miejskiej wymuszającej dokładną ocenę warunków gruntowo-wodnych, na podstawie której wybiera się technologię wykonywania części podziemnych budynku, sposób zabezpieczenia wykopu i podparcia jego ścian, rodzaj fundamentów czy izolacji. Na tym samym etapie projektowania nie można pominąć również wpływu projektowanej inwestycji na budynki już istniejące.

Analiza wpływu realizacji nowych obiektów na już istniejące staje się szczególnie ważna wtedy, gdy sąsiednią zabudowę wzniesiono znacznie wcześniej, tzn. w czasach obowiązywania innych normatywów projektowych oraz stosowania odmiennych technologii budowlanych. Innym aspektem, który należy poddać rozpoznaniu, jest stan technicznych obiektów, w których naprawy i remonty często nie były dokonywane, lub były przeprowadzane zbyt rzadko w stosunku do ich wymagan eksploatacyjnych.

Pierwszym etapem takiej analizy jest określenie zasięgu oddziaływania realizacji nowego obiektu na już istniejące, a następnie wyznaczenie grupy czynników potencjalnie najbardziej destrukcyjnie wpływających. Jednym z nich, niebezpiecznym zarówno w trakcie inwestycji, jak i po jej zakończeniu, są przemieszczenia pionowe powierzchni terenu w sąsiedztwie wykopu, zależne przede wszystkim od rodzaju podłoża gruntowego, zastosowanej obudowy wykopu i przyjętego sposobu jej zabezpieczenia, założonego schematu 
statycznego, ale również harmonogramu realizacji i związanymi z nim stanami odciążenia i obciążenia podłoża gruntowego. Innym równie ważnym czynnikiem jest woda pochodząca $z$ opadów atmosferycznych oraz woda gruntowa działająca bezpośrednio na głęboko posadowioną konstrukcję. Kolejnym destrukcyjnym czynnikiem są obciążenia dynamiczne (np. drgania) i drgania mechaniczne występujące w trakcie prowadzenia robót budowlanych. Drgania te, wraz $\mathrm{z}$ dynamicznymi oddziaływaniami związanymi z ruchem ulicznym odbywającym się w sąsiedztwie inwestycji, moga prowadzić do powiększenia się już istniejących uszkodzeń budynków, a także do powstania nowych, np. pęknięć konstrukcji ścian i stropów (Runkiewicz i Kowalewski, 1999; Potrzebowski, 2006).

Przy analizie pionowych przemieszczeń gruntu, które mogą najbardziej destrukcyjnie wpływać na sąsiednie obiekty, zasięg oddziaływania uzależniony jest od tego, która część obiektu jest realizowana - podziemna czy nadziemna. W przypadku części podziemnej przemieszczenia pionowe powierzchni terenu występują w odległości do około 1,3 wysokości (dalej $h$ ) od krawędzi wykopu, a następnie zanikają. Zasięg ten oraz wartość przemieszczeń pionowych terenu i przemieszczeń poziomych obudowy wykopu są najczęściej wyrażane jako krotność głębokości wykopu $(h)$. Całkowity zasięg oddziaływania realizowanego obiektu (części podziemnej i nadziemnej) wynosi: $-2,8 h$ $\mathrm{w}$ gruntach niejednorodnych z utworami piaszczysty$\mathrm{mi} \mathrm{w}$ strefie posadowienia; $-5,4 h \mathrm{w}$ gruntach niejednorodnych z iłami w strefie posadowienia (Michalak, 2008). Największe przemieszczenia pionowe występują na obszarze o szerokości od $0,5 h$ do $0,75 h$, a zani- kają w odległości około 2,0h (Michalak, Pęski, Pyrak i Szulborski, 1998; Michalak, 2006). Powiększenie tej strefy jest możliwe, gdy nastąpi obniżenia zwierciadła wody gruntowej (wykorzystanie studni depresyjnej) w odległości 3,0-4,0h od krawędzi (Michalak, 2006).

Wskutek działania wymienionych czynników mogą nastąpić zjawiska, takie jak: osiadania gruntów, obniżenie nośności i sztywności istniejących fundamentów, uszkodzenia konstrukcji obiektów budowlanych (powstanie zarysowań i pęknięć elementów konstrukcyjnych) czy uszkodzenia instalacji lub wyposażenia występującego wewnątrz obiektów budowlanych, co w konsekwencji prowadzi do ich stanów awaryjnych (Runkiewicz i Kowalewski, 1999).

\section{ANALIZA ZAGROŻEŃ I AWARII W ODNIESIENIU DO PLANOWANYCH INWESTYCJI}

Rozpatrując zagrożenia, jakim mogą ulec obiekty istniejące w sąsiedztwie planowanej inwestycji budowlanej, można wspomagać się analizą przyczyn awarii i katastrof, do jakich doszło w ciągu ostatnich kilku dekad na terenie Polski. Dane ten gromadzone sa i analizowane w Instytucie Techniki Budowlanej. Na rysunkach 1 i 2 przedstawiono procentowy udział awarii i katastrof w latach 1962-2013 ze względu na rodzaj budownictwa oraz materiały, z jakich zostały one wykonane.

Analizując dane przedstawione na rysunkach 1 i 2 , można stwierdzić, że awarie występują najczęściej w wieloletnich budynkach użyteczności publicznej oraz o przeznaczeniu mieszkalnym, które mają konstrukcję szkieletową lub murowaną. Powodem takiego stanu może być to, że według ówczesnej praktyki

Rys. 1. Udział procentowy awarii i katastrof w latach 1962-2013 ze względu na rodzaj budownictwa (Raporty ITB o zagrożeniach, awariach i katastrofach budowlanych od 1962 r. ..., b.d.)

Fig. 1. A percentage of building accidents in the years 1963-2013 due to the construction type (Raporty ITB o zagrożeniach, awariach i katastrofach budowlanych od 1962 r. ..., n.d.)

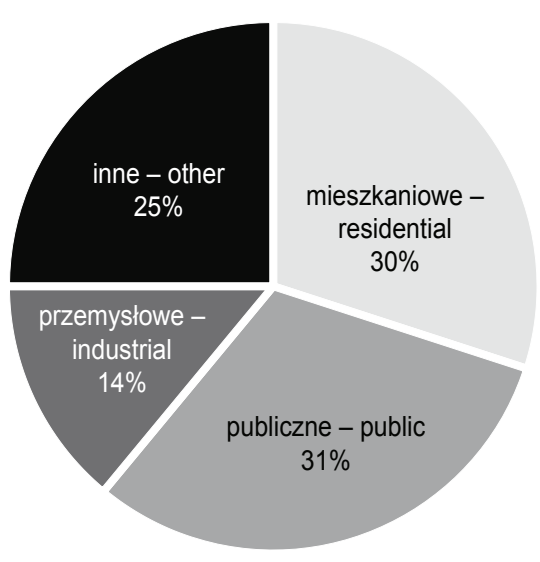


Rys. 2. Udział procentowy awarii i katastrof $w$ latach 1962-2013 ze względu na rodzaj materiały, z jakich zostały wykonane obiekty budowlane (Raporty ITB o zagrożeniach, awariach i katastrofach budowlanych od 1962 r. ..., b.d.).

Fig. 2. A percentage of building accidents in the years 1963-2013 due to the type of construction material (Raporty ITB o zagrożeniach, awariach i katastrofach budowlanych od 1962 r..., n.d.).

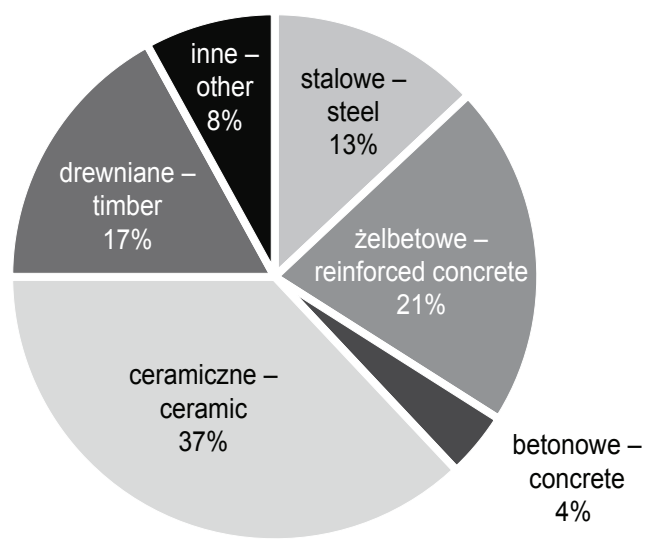

budynki te wzniesiono bez stężeń (wieńców) na poszczególnych kondygnacjach, do tego nie były regularnie konserwowane i remontowane, były natomiast nadmiernie eksploatowane, często niezgodnie ze swoją funkcją. Na tej podstawie można również stwierdzić, że konieczne staje się traktowanie ich jako ustroju technicznego niezwykle skomplikowane ze względu na swoją charakterystykę, trwałość, rodzaj eksploatacji, jakość, technologię wykonania oraz niekorzystny wpływ czynników zewnętrznych, które wymagaja okresowej oceny stanu technicznego z zastosowaniem nowoczesnych metod diagnostyki budowlanej.

Konieczność wykonywania przeglądów okresowych, ocen stanu technicznego, przydatności do użytkowania, ekspertyz budynków i obiektów budowlanych wynika wprost $\mathrm{z}$ zapisów Prawa budowlanego z 1994 r. (art. 61 i 62 rozdz. 6). Dodatkowo zgodnie z praca Brunarskiego i Runkiewicza (2010) można wyróżnić trzy typy diagnostyki:

- okresową - wymagana w związku z użytkowaniem obiektu,

- doraźną - w przypadku uszkodzenia lub istotnych nieprawidłowości w pracy obiektu,

- docelową - gdy planowana jest modernizacja obiektu lub zmiana przeznaczenia oraz gdy planowana jest intestacja budowlana w sąsiedztwie danego obiektu.

Z tych względów przed rozpoczęciem inwestycji należy dokonać diagnostyki zabudowy istniejącej w strefie oddziaływania, a także opracować i wdrożyć program jej monitoringu geodezyjnego i wizualnego. Obiekty budowlane, w tym szczególnie długoletnie, powinny być obligatoryjnie poddane ocenie stanu technicznego. Konstrukcja obiektów, które sąsiadują z planowaną inwestycją, powinna mieć możliwość przeniesienia dodatkowych obciążeń spowodowanych nierównomiernym przemieszczaniem się podłoża w strefie posadowienia albo, jeżeli konstrukcji nie jest w stanie przenieść takich obciążeń, powinna być możliwość wprowadzenia dodatkowych wzmocnień (Szulborski, Michalak i Woźniak, 2009).

Podczas wizji lokalnej budynku (niezbędny aspekt oceny stanu technicznego) koniecznie trzeba określić wiek budynku, ustalić rodzaj konstrukcji, rodzaj gruntu w posadowieniu budynku, rodzaj konstrukcji przekrycia dachowego i jego poszycia, rozwiązania materiałowe oraz sposób użytkowania budynku (jaki był przyjęty w projekcie i jaki jest aktualny), a także zidentyfikować występujące uszkodzenia elementów konstrukcji i infrastruktury. Ponadto konieczne jest ustalenie czynników występujących w trakcie eksploatacji budynku, mających duży wpływ na stan techniczny głównych elementów konstrukcji, np. awarie sieci uzbrojenia podziemnego w pobliżu budynków, pożary itp. (Kawecki, 1999; Kuleta, Pikos i Słowek, 2009).

\section{METODYKA DZIAŁAŃ}

Niniejsza praca ma na celu przedstawienie wykonanej oceny stanu technicznego budynku mieszkalnego wielorodzinnego zlokalizowanego na warszawskiej Pradze, a także analizy wykonanych w budynku napraw i wzmocnień, które wskazano $\mathrm{w}$ zaleceniach wspomnianej oceny, koniecznych do doprowadzenia obiektu do stanu użytkowalności. Ekspertyzę wykonano w związku z planowaną inwestycją komunikacyjną 
w bezpośrednim sąsiedztwie obiektu. W zakresie opracowania znajduje się ocena newralgicznych punktów budynku i porównanie stanu technicznego przed dokonanymi pracami naprawczymi i po nich.

\section{OPIS OBIEKTU ORAZ JEGO STANU TECHNICZNEGO}

Przedmiotowy obiekt jest budynkiem mieszkalno-usługowym zamieszkania wielorodzinnego, zlokalizowanym w dzielnicy Praga Północ w Warszawie. Budynek powstał w 1912 roku. Składa się z części frontowej oraz oficyny, całość ma kształt litery L. W budynku znajduje się 68 lokali mieszkalnych oraz 20 lokali użytkowych. Obiekt ma pięć kondygnacji naziemnych, strych oraz jedną kondygnację podziemną, która wychodzi poza obrys budynku. Budynek nie ma wind, komunikację pionową zapewniają trzy klatki schodowe. Cechą charakterystyczną budynku jest jego nieotynkowana elewacja ceglana. Na elewacji frontowej znajdują się elementy ozdobne.

Budynek wykonano w technologii tradycyjnej murowanej. Układ konstrukcyjny w części frontowej jest mieszany, a w oficynie - jednotraktowy. Ściany kondygnacji podziemnych wykonano z cegły ceramicznej pełnej na zaprawie wapiennej, ściany zewnętrzne - 3 cegły, ściany nośne wewnętrzne - 3 cegły oraz 1,5 cegły. Ściany nośne kondygnacji naziemnych wykonane w takiej samej technologii, o następujących grubościach: 2,5 cegły - parter i I piętro, 2 cegły - II, III i IV piętro. Obiekt posadowiony jest bezpośrednio. Ławy oraz schodkowe stopy wykonano z cegły pełnej na zaprawie cementowo-wapiennej, $\mathrm{z}$ obustronnymi odsadzkami o grubości $6-7 \mathrm{~cm}$.

W budynku pierwotnie występowały trzy rodzaje stropów: stalowo-ceramiczne typu Kleina (nad piwnicą, parterem, I, II i III kondygnacją oraz częściowo nad IV kondygnacją), drewniane (częściowo nad IV piętrem) oraz żelbetowe nad piwnicami wychodzącymi poza obrys budynku (strop wykonany w latach 60. ubiegłego wieku). Klatki schodowe w zależności od lokalizacji wykonano jako żelbetowe płytowe, oparte na belkach żelbetowych lub jako policzkowe, stalowe oparte na stalowych belkach ceowych spoczników. Bieg schodów prowadzący do piwnicy wykonano $\mathrm{z}$ drewna.
Cechą charakterystyczną części frontowej budynku jest dwuspadowa więźba dachowa o konstrukcji krokwiowo-płatwiowej. Nachylenie połaci dachu w tej części wynosi około $16,0^{\circ}(\sim 28,5 \%)$. W oficynie występuje jednospadowa więźba pulpitowa o stolcu pochyłym z zastrzałem. Nachylenie połaci dachu w tej części wynosi około $17,5^{\circ}(\sim 31,5 \%)$. Trzony kominowe budynku, murowane z cegły ceramicznej pełnej, stanowią część ściany nośnej (nie są niezależnymi konstrukcjami).

Stan ogólny omawianego budynku oceniono jako zły i awaryjny, a poziom zużycia technicznego określono na $75,39 \%$, co kwalifikuje go do wyłączenia $\mathrm{z}$ użytkowania. W trybie pilnym wymagany był kapitalny remont budynku, co wiąże się z zabezpieczeniem elementów konstrukcyjnych budynku. Awaryjny stan techniczny stwarzał bezpośrednie zagrożenie zdrowia i życia ludzkiego oraz mienia.

Szczegółowy stan techniczny podstawowych elementów konstrukcyjnych zestawiono w kolejnym rozdziale tego artykułu. Na szczególną uwagę zasługują fundamenty obiektu, których zużycie określono na 80 $-90 \%$. W związku z tym istniało realne zagrożenie utraty nośności podłoża, zwłaszcza w sytuacji dodatkowego narażenia podłoża gruntowego oraz fundamentów na oddziaływania planowanej inwestycji komunikacyjnej.

Po analizie stanu technicznego zdecydowano się na przeprowadzenie kapitalnego remontu budynku, łącznie ze wzmocnieniem elementów konstrukcyjnych. Podyktowane było to tym, że obiekt wpisano 13 lipca 2012 r. do rejestru zabytków (ochrona bezpośrednia) pod nazwą Kamienica Marii Galeotti.

\section{ANALIZA PRZEPROWADZONYCH WZMOCNIEŃ ORAZ STAN ELEMENTÓW KONSTRUKCYJNYCH PO WYKONANIU PRAC}

Z uwagi na newralgiczną lokalizację budynku względem dużej inwestycji komunikacyjnej, której oddziaływanie miało bezpośredni wpływ na jego bezpieczeństwo, wzmocniono podłoże gruntowe poniżej poziomu posadowienia. Zastosowano do tego niskociśnieniowe iniekcje podłoża zaczynem cementowo-bentonitowym, umożliwiając mechaniczne i hydrauliczne wzmocnienie podłoża gruntowego, aby zminimalizować mogące powstać odkształcenia gruntowe (Lombardi i Capata, 2017). 
Dohojda, M., Jeleniewicz, K., Witkowska-Dobrev, J., Szlachetka, O. (2020). Stan techniczny przedwojennych budynków w obliczu nowych inwestycji komunikacyjnych na przykładzie kamienicy z 1912 roku. Acta Sci. Pol. Architectura, 19 (3), 3-14. doi: 10.22630/ ASPA.2020.19.3.22

W celu ustabilizowania naprężeń pod ławami fundamentowymi wykonano żelbetowy ruszt w poziomie istniejącej posadzki, w piwnicach obiektu. W ścianach zewnętrznych belki zewnętrzne zostały zazbrojone podłużnie $2 \times \varnothing 20 \mathrm{~mm}$ górą i dołem oraz zastosowano w nich strzemiona dwucięte $\varnothing 8 \mathrm{~mm}$, co $20 \mathrm{~cm}$. W strefie ścian poprzecznych wykonano przewierty przez ścianę w celu wprowadzenia zbrojenia (miejsce uciąglenia). Bezpieczne przekazywanie obciążeń ze ścian na ruszt zagwarantowało wstawienie profili HEB120. Wykonano również izolacje przeciwwodne budynku. Posadzka została zazbrojona przy wykorzystaniu prętów $\varnothing 12 \mathrm{~mm}$, co $20 \mathrm{~cm}$ górą i dołem, z wypełnieniem pomiędzy rusztem belkowym. Grubość posadzki wynosi obecnie $20 \mathrm{~cm}$. W celu zapewnienia współpracy posadzki oraz układu belki żelbetowe z profilem zastosowano łączniki zbrojeniowe spawane do profili HEB.

Rysunki 3 i 4 ilustrują zakres prac naprawczych wzmocnienia konstrukcji podziemnej - wyrównanie ścian oraz usunięcie śladów zawilgocenia, wykwitów grzybów i pleśni, które pojawiły się wskutek braku izolacji przeciwwodnych pionowych i poziomych ścian fundamentowych (Stawiska i Stawiski, 2005; Orłowicz i Tkacz, 2016; Hoła, 2019).

Podłużne i poprzeczne ściany konstrukcyjne nadziemne wzmocniono za pomocą systemu ściągów.

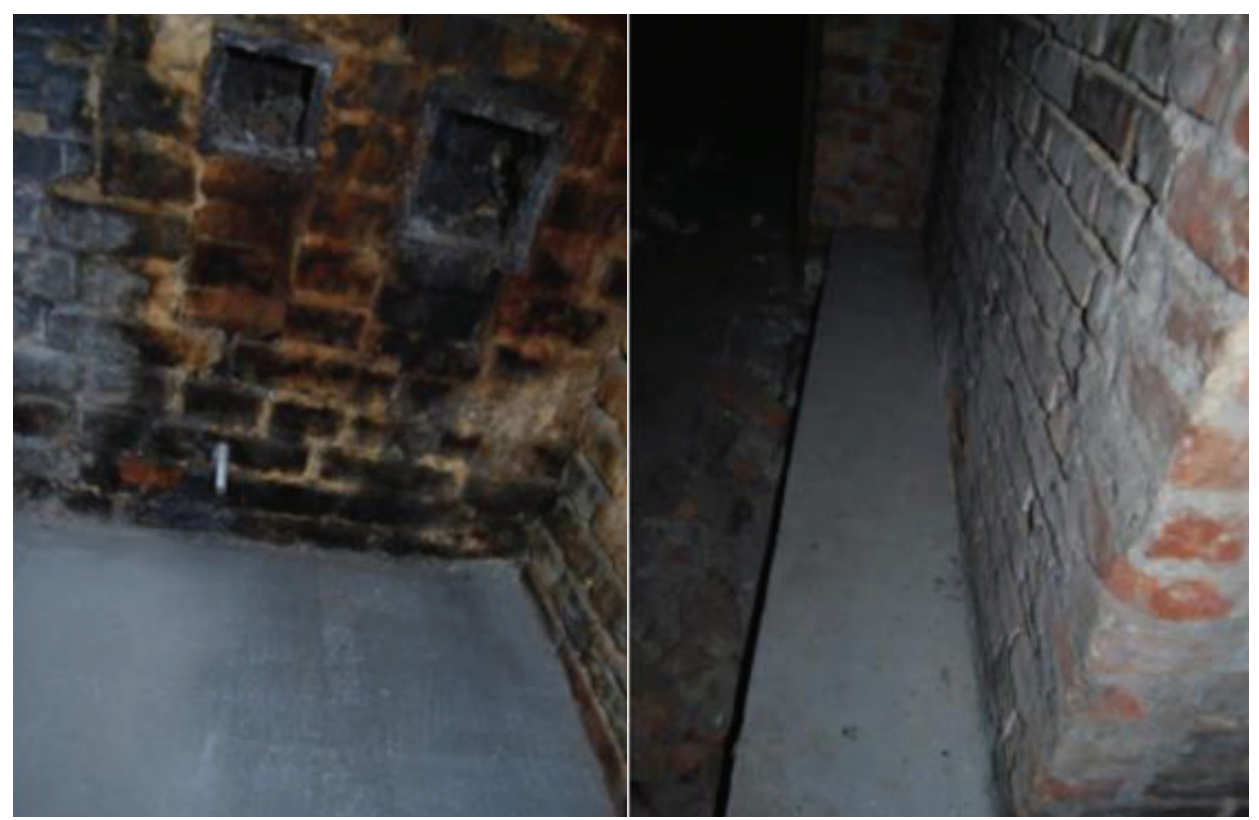

Rys. 3. Żelbetowy ruszt oraz posadzka z izolacją przeciwwodną

Fig. 3. The reinforced concrete grate and the tiles with waterproofing isolation
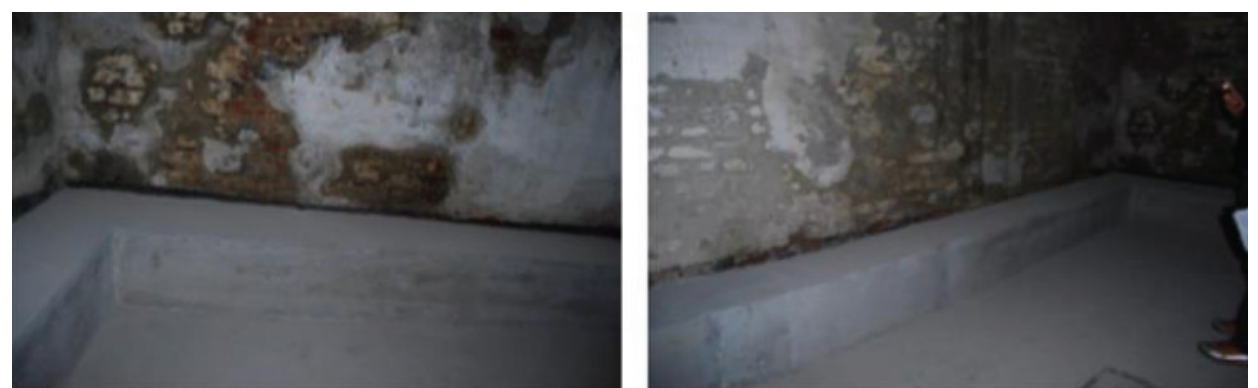

Rys. 4. Ruszt żelbetowy oraz wyrównane i naprawione ściany fundamentowe

Fig. 4. The reinforced concrete grate and leveled and fixed ground wall 
Dohojda, M., Jeleniewicz, K., Witkowska-Dobrev, J., Szlachetka, O. (2020). Stan techniczny przedwojennych budynków w obliczu nowych inwestycji komunikacyjnych na przykładzie kamienicy z 1912 roku. Acta Sci. Pol. Architectura, 19 (3), 3-14. doi: 10.22630/ ASPA.2020.19.3.22

Ze względu na naprężenia rozciągające występujące w płaszczyźnie ściany oraz na potrzeby zrównoważenia sił wynikających z odchylenia środka ciężkości ściany od jej osi, zaprojektowano system ściągów jako pręty systemowe SAS1100, blachy profilowe ze stali St3SX, a śruby i podkładki klasy 5.6. Ściąi wykonano na pięciu poziomach: parter, piętro +1 , piętro +2 , piętro +3 , piętro +4 . Systemy umieszczono nad lub pod stropami. System ściągów przedstawiono na rysunku 5 (Chmielewski, Kruszka i Lalka, 2016).

Największe pionowe zarysowania ścian zewnętrznych budynku występowały na tylnej ścianie oficyny, przy czym szerokość rys sięgała $2 \mathrm{~cm}$ rozwarcia. Rysy były zlokalizowane głównie wzdłuż kominów na całej ich wysokości oraz w miejscach osadzenia stalowych belek spoczników klatki schodowej. Naprawa rysy została przeprowadzona z zastosowaniem prętów Brutt Saver $\varnothing 8 \mathrm{~mm}$, wklejanych w fugi między cegłami co trzeci rząd. Fugi te następnie wypełniano zaprawą Brutt Saver Powder. Wzmocnioną i naprawioną ścianę przedstawiono na rysunkach 6 i 7 .

W stropie typu Kleina znajdującego się nad piwnica, w obrysie naziemnych kondygnacji budynku, występowały znaczne uszkodzenia belek stropowych $\mathrm{w}$ postaci wżer i rozwarstwień spowodowanych korozją. W stropie występowały również liczne miejscowe uszkodzenia mechaniczne, liczne ubytki cegieł i zaprawy powstałe w wyniku nieodpowiedniego wykonywania otworów instalacyjnych. Strop ten wymieniono na żelbetowy, krzyżowo zbrojony o grubości 22-24 cm, który dosztywnił cała konstrukcję budynku. Nad pozostałymi kondygnacjami
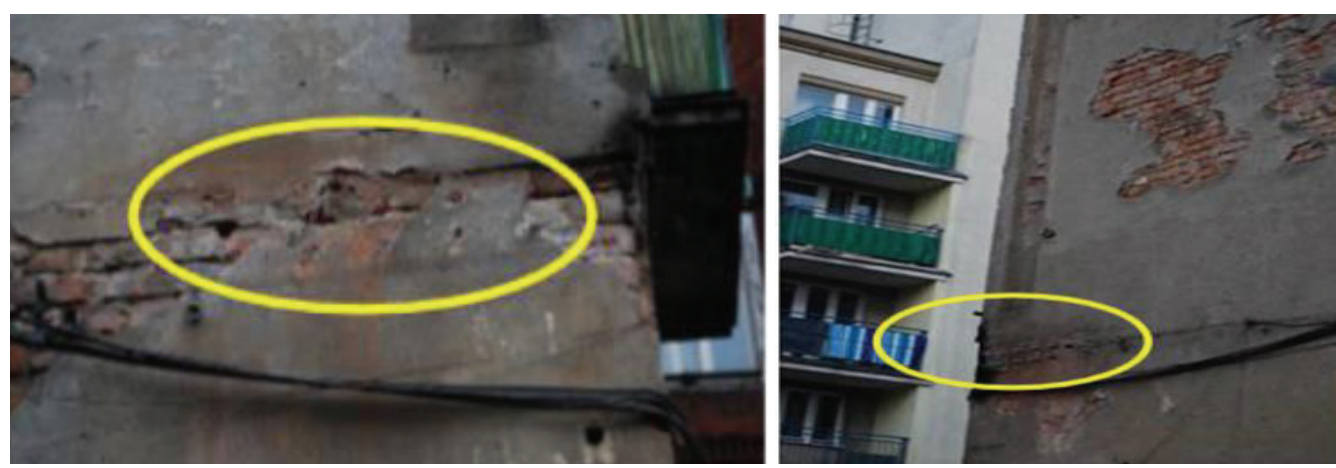

Rys. 5. System ściągów umieszczone nad lub pod stropami

Fig. 5. The system of brace coils above or below the ceiling
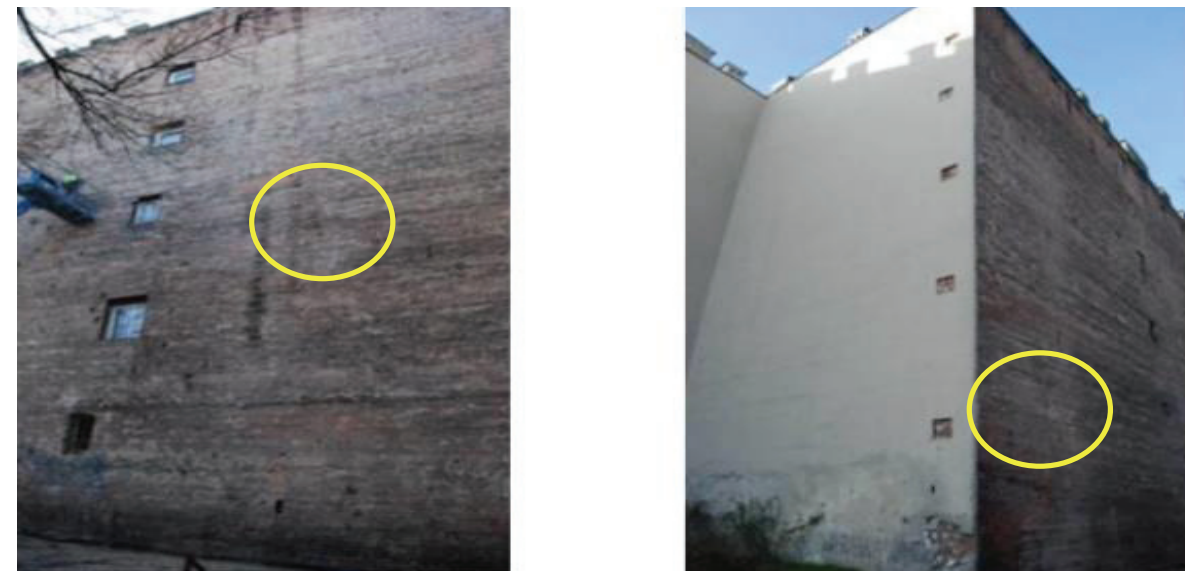

Rys. 6. Naprawione rysy wzdłuż kominów ściany szczytowej budynku

Fig. 6. Fixed cracks along chimneys in front wall of the building 
Dohojda, M., Jeleniewicz, K., Witkowska-Dobrev, J., Szlachetka, O. (2020). Stan techniczny przedwojennych budynków w obliczu nowych inwestycji komunikacyjnych na przykładzie kamienicy z 1912 roku. Acta Sci. Pol. Architectura, 19 (3), 3-14. doi: 10.22630/ ASPA.2020.19.3.22

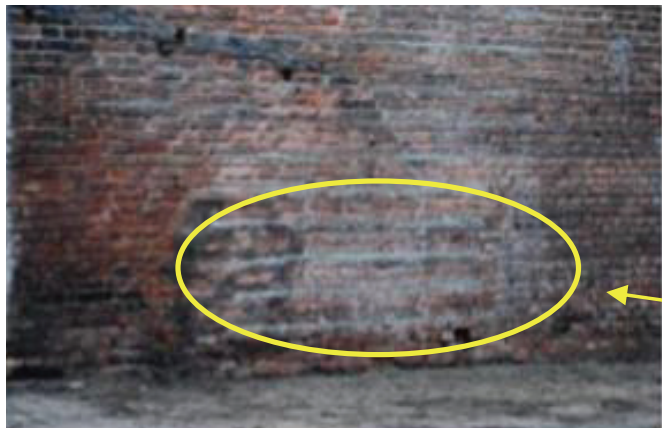

Rys. 7. Widok tylnej ściany budynku - naprawione rysy

Fig. 7. The view of back wall of the building - fixed cracks

stropy zostały wzmocnione przez zastosowanie prętów wzmacniających, wklejanych chemicznie i kotwionych w ścianach zewnętrznych. Zakres obejmujący wzmocnienie i naprawę stropów przedstawiono na rysunkach 8 i 9 .

Zabiegi mające na celu wzmacnianie i przywrócenie stanu umożliwiającego eksploatację budynku

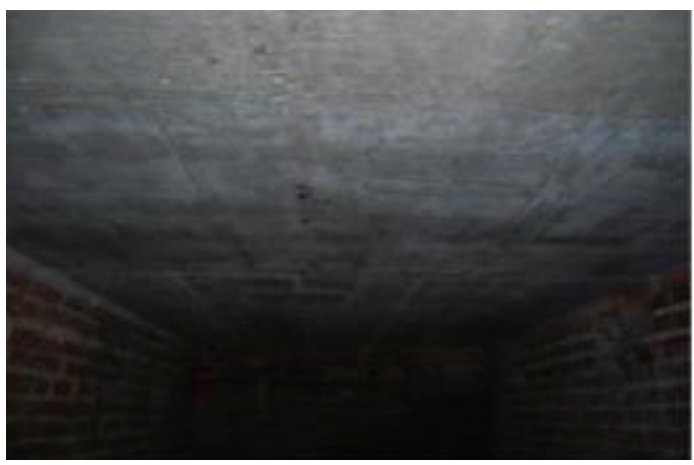

Rys. 8. Strop żelbetowy

Fig. 8. The reinforced concrete ceiling

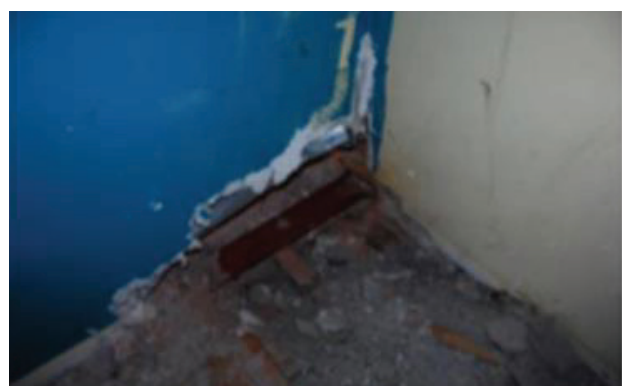

Rys. 9. Wzmocnienie stalowych belek stropowych

Fig. 9. The reinforcement of steel ceiling beams

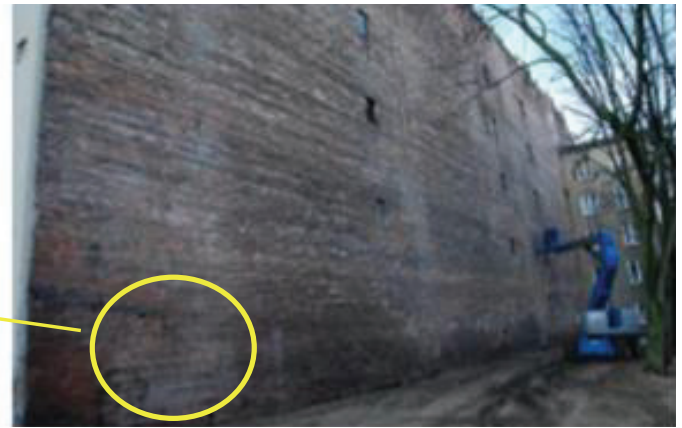

przeprowadzono prawidłowo zgodnie $\mathrm{z}$ wiedzą techniczną. Wpłynęły one na poprawę stanu technicznego obiektu, co pozwoliło na jego dalszą renowację i przywrócenie do użytkowania. Po dokonaniu napraw i wzmocnień obiekt powtórnie poddano ocenie. Zestawienie oceny stanu technicznego przed wykonanymi pracami i po nich przedstawiono w tabeli.
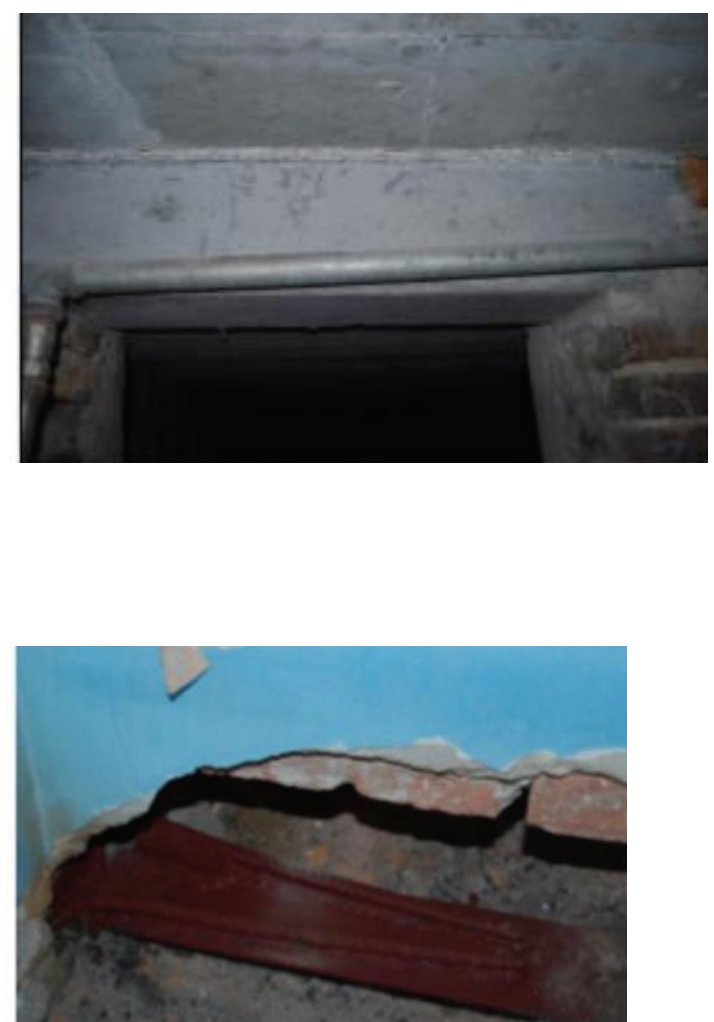


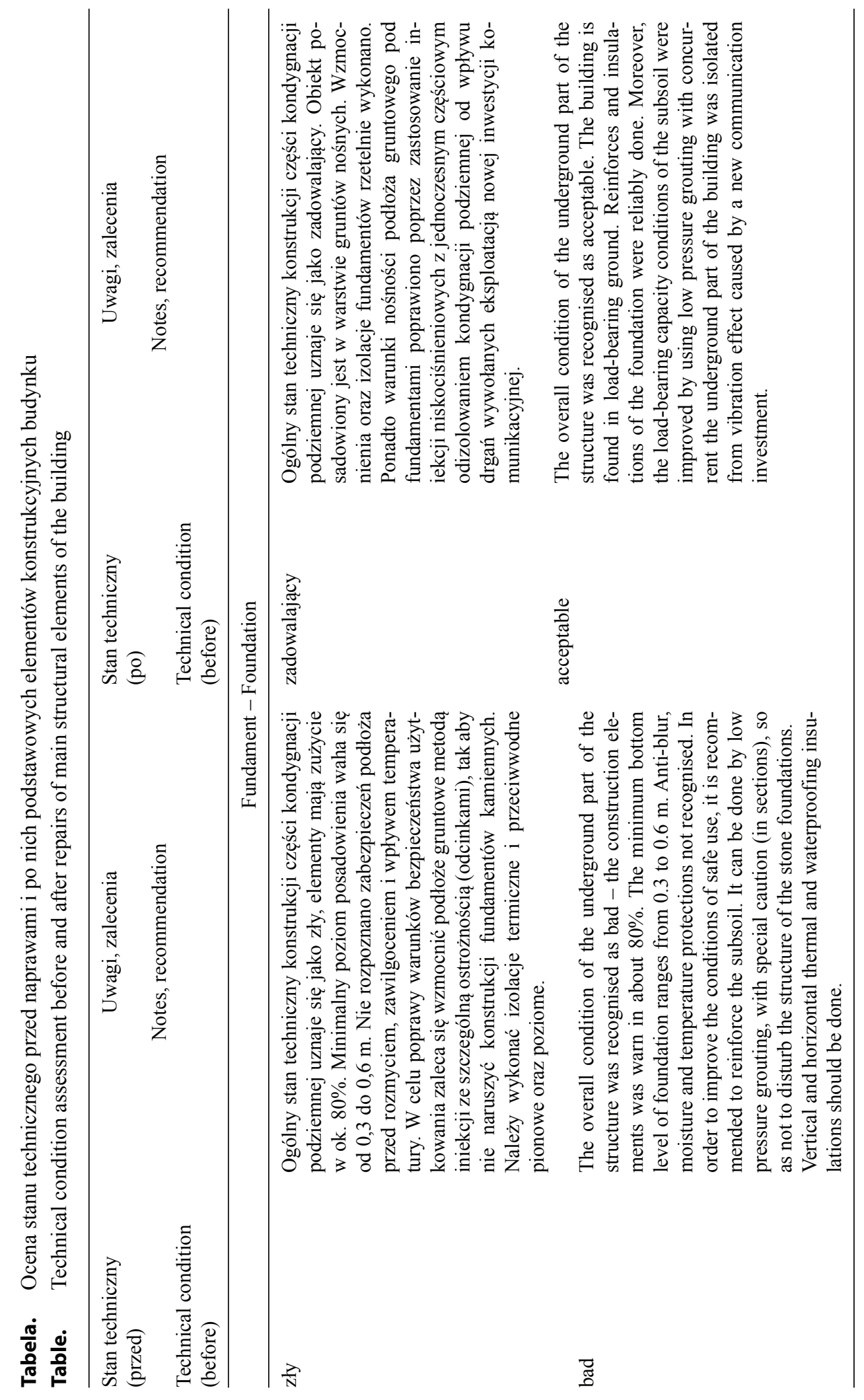




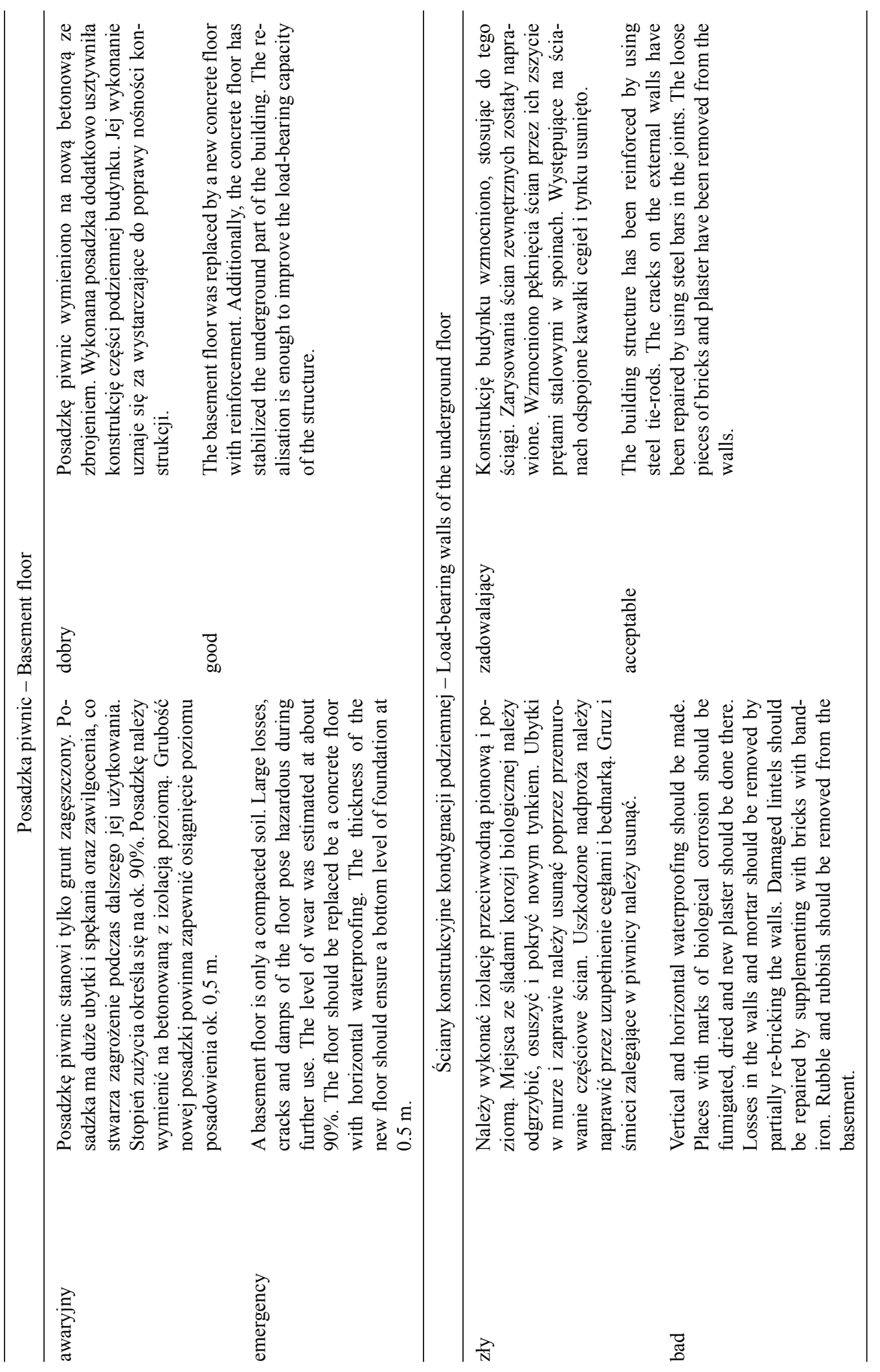




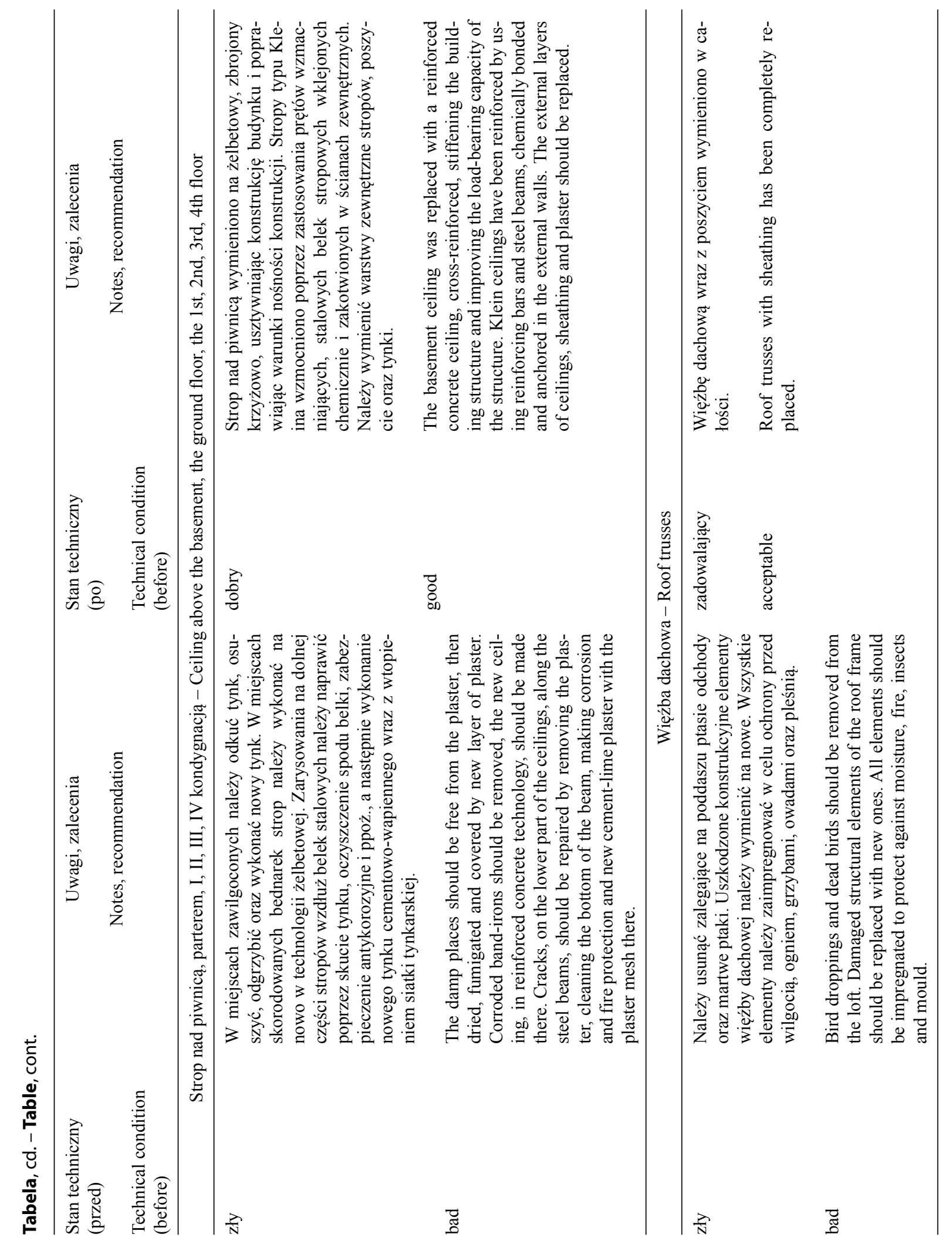


Dohojda, M., Jeleniewicz, K., Witkowska-Dobrev, J., Szlachetka, O. (2020). Stan techniczny przedwojennych budynków w obliczu nowych inwestycji komunikacyjnych na przykładzie kamienicy z 1912 roku. Acta Sci. Pol. Architectura, 19 (3), 3-14. doi: 10.22630/ ASPA.2020.19.3.22

\section{WNIOSKI}

Realizacja inwestycji w warunkach gęstej zabudowy śródmiejskiej jest bardzo złożonym problemem. Poza spełnieniem obowiązujących norm i wytycznych istotna staje się kwestia profesjonalnego przygotowania tego typu inwestycji oraz prowadzenia robót zgodnie z wiedzą techniczną. Konieczne jest również określenie strefy oddziaływania projektowanego obiektu na istniejącą zabudowę oraz dopełnienie bezpieczeństwa użytkowania tej zabudowy oraz istniejącej infrastruktury technicznej. Ważnym aspektem jest również prawidłowa ocena stanu technicznego istniejących obiektów, w szczególności wieloletnich nieodpowiednio konserwowanych. Wskutek oddziaływań nowych inwestycji w sąsiedztwie stan ten może jeszcze ulec znacznemu pogorszeniu lub nawet może dojść do awarii lub katastrofy budowlanej.

$\mathrm{Na}$ podstawie pierwotnej oceny stanu technicznego opisany w niniejszej pracy obiekt budowlany zakwalifikowano jako awaryjny, gdyż stwarzał bezpośrednie zagrożenie zdrowia i życia ludzkiego oraz mienia. Każde oddziaływanie sąsiednich inwestycji mogło doprowadzić do jego całkowitego zniszczenia. W tym celu przeprowadzono w nim wiele opisanych w artykule prac naprawczych, które doprowadziły go do użytkowalności, umożliwiły w nim dalsze prace renowacyjne, a także zabezpieczyły go przed negatywnym wpływem realizowanej obecnie w jego sąsiedztwie inwestycji komunikacyjnej.

\section{Indywidualny wkład autorów}

Koncepcja pracy: J.W.-D., K.J.; metodyka: K.J., M.D., O.S.; analiza formalna: M.D., K.J., J.W.-D., O.S.; zasoby: M.D.; kompilacja i opracowanie danych: K.J., J.W.-D., O.S.; sporządzenie wstępnej wersji artykułu: J.W.-D.; redakcja i korekta artykułu: K.J., M.D., O.S.; wizualizacja i oprawa graficzna: M.D., K.J., J.W.-D., O.S.

Wszyscy autorzy zapoznali się z przeznaczoną do publikacji wersją manuskryptu.

\section{PIŚMIENNICTWO}

Brunarski, L. i Runkiewicz, L. (2010). Diagnostyka obiektów budowlanych. Referat na 56. Konferencji Naukowej Komitetu Inżynierii Lądowej i Wodnej PAN oraz Komitetu Nauki PZITB, 19-24.09.2010. Kielce-Krynica.

Chmielewski, R., Kruszka, L. i Lalka, J. (2016). Aspekty przebudowy zabytkowych budynków murowanych o bezwieńcowej konstrukcji stropów międzykondygnacyjnych. Biuletyn Wojskowej Akademii Technicznej, 65 (4), 123-141.

Hoła, J. (2019). Degradacja budynków zabytkowych wskutek nadmiernego zawilgocenia - wybrane problemy. Budownictwo i Architektura, 17 (1), 133-148.

Kawecki, J. (1999). Uwzględnienie wpływów dynamicznych przy inwestycjach w obszarach zurbanizowanych. W V Konferencji Naukowo-Technicznej „Warsztat Pracy Rzeczoznawcy Budowlanego", 27-29.04.1999, Kielce (strony 119-138). Kielce: Polski Związek Inżynierów i Techników Budownictwa.

Kuleta, P., Pikos, M. i Słowek, G. (2009). Problemy konstrukcyjne remontowanego budynku zabytkowego. Wiadomości Konserwatorskie, 26, 637-645.

Lombardi, A. i Capata, V. (2017). Soil improvement for building foundation - d16.33. Roma: Studio Geotecnico Strutturale.

Michalak, H. (2006). Ksztaltowanie konstrukcyjno-przestrzenne garaży podziemnych na terenach silnie zurbanizowanych. Prace Naukowe Politechniki Warszawskiej. Architektura. Tom 2. Warszawa: Oficyna Wydawnicza Politechniki Warszawskiej.

Michalak, H. (2008). Budynki głęboko posadowione a przemieszczenia podłoża i zabudowy w sąsiedztwie. Geoinżnieria: Mosty, Drogi, Tunele, 4, 66-67.

Michalak, H., Pęski, S., Pyrak, S. i Szulborski, K. (1998). O wpływie wykonywania wykopów głęboki na zabudowę sąsiednią. Inżynieria i Budownictwo, 1, 12-15.

Orłowicz, R. i Tkacz, P. (2016). Nośność i naprawa niejednorodnych ścian murowych budynków zabytkowych. Materiaty Budowlane, 1 (12), 58-60.

Potrzebowski, J. (2006). Parkingi i garaże. Część II. Trwałość obiektu i bezawaryjna eksploatacja. Builder, 7/8, 72-74.

Raporty ITB o zagrożeniach, awariach i katastrofach budowlanych od 1962 r. (Temat NK-45, gł. referent L. Runkiewicz) [b.d.]. Instytut Techniki Budowlanej, Warszawa [nieopublikowane]. 
Dohojda, M., Jeleniewicz, K., Witkowska-Dobrev, J., Szlachetka, O. (2020). Stan techniczny przedwojennych budynków w obliczu nowych inwestycji komunikacyjnych na przykładzie kamienicy z 1912 roku. Acta Sci. Pol. Architectura, 19 (3), 3-14. doi: 10.22630/ ASPA.2020.19.3.22

Runkiewicz, L. i Kowalewski, J. (1999). Diagnostyka i wzmocnienia istniejących budynków przy realizacji „plomb”. W V Konferencja Naukowo-Techniczna „Warsztat Pracy Rzeczoznawcy Budowlanego”, Kielce (strony 211-224). Kielce: Polski Związek Inżynierów i Techników Budownictwa.

Stawiska, N. i Stawiski, B. (2005). Rewaloryzacja murów w obiektach zabytkowych. Wiadomości Konserwatorskie, 18, 18-22.
Szulborski, K., Michalak, H. i Woźniak, M. (2009). Zabezpieczenia i obserwacje obiektów w sąsiedztwie głębokich wykopów. W XXIV Ogólnopolskie Warsztaty Pracy Projektanta Konstrukcji „Naprawy i wzmocnienia konstrukcji budowlanych", Wisła. Tom III (strony 229-264). Kraków: Polski Związek Inżynierów i Techników Budownictwa.

Ustawa z dnia 7 lipca 1994 r. - Prawo budowlane. Dz.U. 1994 nr 89, poz. 414 z późn. zm.

\section{TECHNICAL CONDITION OF PRE-WAR BUILDINGS IN THE FACE OF NEW TRANSPORT INVESTMENTS ON THE EXAMPLE OF A TOWNHOUSE FROM 1912}

\section{ABSTRACT}

The subject of the paper is an analysis a new building investments impact on the already existing buildings in a tight, compact city construction. The problem was discussed in two ways in the paper. Firstly, by identifying a group of factors that are caused by a new construction investments which could effect on neighbouring objects. Secondly, by correct technical condition assessment of existing buildings, methods for improving it or using technologies, that are also aimed to minimising the neighbouring investments impact. The issue was discussed based on a pre-war building located in the Praga Północ District in Warsaw.

Key words: technical condition assessment, pre-war buildings, transport investments, investment impact zone 